\title{
In Vitro Antiaging Analysis of Topical Pharmaceutical Preparation Containing Mixture of Strawberry Fruit, Pomelo Peel, and Langsat Fruit Extracts
}

\author{
Endang Lukitaningsih ${ }^{* *}$, Anjar Hermadi Saputro ${ }^{2}$, Mirna Widiasri ${ }^{2}$, Nibras Khairunnisa ${ }^{2}$, Nisrina \\ Prabaswari ${ }^{2}$, Rina Kuswahyuning ${ }^{3}$ \\ 'Department of Pharmaceutical Chemistry, Faculty of Pharmacy, Gadjah Mada University, Yogyakarta, \\ Indonesia \\ ${ }^{2}$ Faculty of Pharmacy, Gadjah Mada Univeristy, Yogyakarta, Indonesia \\ ${ }^{3}$ Department of Pharmaceutics, Faculty of Pharmacy, Gadjah Mada University, Yogyakarta, Indonesia \\ *Corresponding author: Endang Lukitaningsih I email: lukitaningsih end@ugm.ac.id; \\ Tel.: (+62-274-543120)
}

Received: 1 January 2021; Revised: 11 February 2021; Accepted: 12 February 2021; Published: 14 February 2021

\begin{abstract}
The previous research has discovered that strawberry fruit, pomelo peel and langsat fruit peel have antioxidant activity. This research aimed to put the extract combination into several formula of gel and cream. Extract will be formulated into two gels with Natrium Carboxyl Methyl Cellulose as gelling agent for Formula 1 and Synthalen for Formula 2. Whereas there are three cream formulations with Glyceril Mono Stearat as surfactant for Formula 3, Polawax for Formula 4, and Simulsol 165 for Formula 5. Natrosol HBr was added to Formula 3 as thickening agent and Keltrol CG-SFT added to Formula 5. After five formulas being made, their stability was tested using climatic chamber within 30 days. Physical stability parameters were spreadability, stickiness, $\mathrm{pH}$, viscosity, separation degree, and syneresis test. The chemical properties evaluation of the formula was done by measuring radical 2,2difenyl-1-pikrylhidrazil (DPPH) scavenging activity percentage, anti-collagenase activity, antityrosinase activity, and anti-elastase activity. The results showed that all of formulas have good activity in scavenging DPPH radical, anti-elastase, anti-collagenase and anti-tyrosinase as well. In addition, all formulas have good stability. There is no change in appearance after three times freeze-thaw cycle. Therefore, it was concluded that all formula can be developed as topical preparation for antiaging. Keywords: antiaging, antioxidant, anti-tyrosinase, anti-collagenase, anti-elastase
\end{abstract}

\section{INTRODUCTION}

Aging is defined as a physiological process characterized by continuously homeostatic loss that involves all members of the body [1] . Skin aging is induced by intrinsic and extrinsic factors [2,3]. Skin aging is intrinsically slower and shows significant variation in each individual. Intrinsic aging occurs within tissue through the reduction of dermal cells, fibroblasts, and collagen production [4]. Meanwhile, extrinsic aging can be caused by exposure to the environment, especially solar UV radiation or ultraviolet [5]. UV radiation can induce biological responses, leading to skin damage through the generation of reactive oxygen species (ROS) [6].

Excessive sun light exposure can cause adverse effects such as erythema, sunburn, skin degeneration such as premature aging and skin cancer [5]. However, these side effect can be prevented by antioxidant material such as dietary vitamin and polyphenol $[7,8]$. As already well known, the 
presence of free radicals in the body can trigger the acceleration of collagenase and elastase production which in normal conditions exist in the skin. Increasing collagenase and elastase enzyme will further accelerate the breakdown of collagen and then became skin aging [9]. In addition, UV light can accelerate the activity of the tyrosinase enzyme to produce melanin in the skin [10]. One strategy that can inhibit the skin aging is using topical pharmaceutical preparations that contain antiaging agents on the skin. Semisolid preparations containing active compounds from plants can be selected as one of the options such as using extract of strawberry, langsat and pomelo peel. The antioxidant and anticollagenase activities of each extract used in this study are already known by IC $_{50}$ value. Based on Qonita (2017) research, ethanolic extract of strawberry fruit has IC 50 value for scavenging radical DPPH around $0,496 \pm 1,05 \mathrm{mg} / \mathrm{mL}$ [11]. Meanwhile, ethanolic extract of langsat fruit has IC 50 for anti-tyrosinase was $124 \pm 0,04 \mu \mathrm{g} / \mathrm{mL}$ [12]. In addition, It was reported that ethanolic extract of pomelo peel peel has the percentage of anti-collagenase activity is $25,85 \pm 0,49 \%$ in $50 \mu \mathrm{g} / \mathrm{mL}$ concentration [13].

This study aimed to make a combination of ethanolic extract of strawberry fruit, langsat fruit, and pomelo peel peel and then formulate them into semisolid preparations such as gel and cream. In addition, physical and chemical stability of the preparation will be evaluated. The physical stability parameter that will be evaluated are spreadability, stickiness, $\mathrm{pH}$, viscosity, syneresis and separation degree. The chemical stability parameters that will be evaluated are radical 2,2-diphenyl-1pikrylhidrazil (DPPH) scavenging, anti-collagenase, anti-tyrosinase, and anti-elastase as well.

\section{MATERIALS AND METHODS}

Materials used in this research included F. $\mathrm{x}$ ananassa was obtained in a strawberry plantation of Banyuroto Village, Magelang District, Central Java Province, L. domesticum was obtained from the langsat plantation of Siwa District, South Sulawesi, C. maxima was obtained in Imogiri, Bantul District, Yogyakarta, Ethanol (JT-Baker, USA), Methanol (JT-Baker, 31 USA), Ascorbic Acid (Merck, Germany), Keltrol, 1,2-diphenyl-2-picrilhydrazyl (DPPH) (sigma, USA), Natrium Acetate, Enzyme Collagenase (MMP-1) (Enzo Life Science, USA), Na-CMC, Synthalen, Triethanolamin, Glycerin Mono Stearate, Natrosol HNr, Polawax, Simulsol 165, KOH, Keltrol, Jojoba oil, Propyleneglycol, Glycerine, Nipagin, Nipasol.

\subsection{Sample preparation and extraction}

Five kilograms of each strawberry (Fragaria $x$ ananassa), pomelo peel (Citrus maxima) and langsat fruit (Lansum domesticum) were washed using clean water. Then strawberry were milled by blender, langsat fruit were separated between peel, flesh and its seed. Then the flesh of langsat were milled by blender. Pomelo peel were dried and milled into powder.

The flesh fruit of strawberry (F. $x$ ananassa) and langsat (L. domesticum) that have been milled and also the powder of pomelo peel (C. maxima) were extracted with etanol $96 \%$ in 3 days using maceration method. Then, they were filtered and evaporated using evaporator on $50^{\circ} \mathrm{C}$ until they were be viscous extract. Then check the yield (\%), lost on drying and $\mathrm{pH}$ of each extracts.

Combination extract was prepared by mixture in the same ratio of extract strawberry-pomelo peellangsat (1:1:1)

\subsection{Formulation of gel and cream}

Five formulas were prepared using composition as in Table I to performed creams (Formula 1, 2 and 3) and gels (Formula 4 and 5). 
Table 1. Formula cream and gel

\begin{tabular}{|c|c|c|c|c|c|c|c|c|c|}
\hline \multicolumn{2}{|c|}{ Formula 1} & \multicolumn{2}{|c|}{ Formula 2} & \multicolumn{2}{|c|}{ Formula 3} & \multicolumn{2}{|c|}{ Formula 4} & \multicolumn{2}{|c|}{ Formula 5} \\
\hline Mixed & & Mixed & & Mixed & & Mixed & & Mixed & \\
\hline extract & $1 / 0$ & extract & $1 / 0$ & extract & $1 / 0$ & extract & $1 / 0$ & extract & $1 / 0$ \\
\hline $\mathrm{Na}-\mathrm{CMC}$ & $2 \%$ & Synthalen & $2 \%$ & $\begin{array}{l}\text { Glyceril } \\
\text { Mono } \\
\text { Stearate }\end{array}$ & $7 \%$ & Polawax & $7 \%$ & $\begin{array}{l}\text { vintuiver } \\
165\end{array}$ & $7 \%$ \\
\hline $\begin{array}{l}\text { Propylene } \\
\text { glycol }\end{array}$ & $15 \%$ & $\begin{array}{l}\text { Irietanola } \\
\text { min }\end{array}$ & q.s. & Jojoba Oil & $5 \%$ & Jojoba Oil & $5 \%$ & Jojoba Oil & $5 \%$ \\
\hline Glycerine & $30 \%$ & $\begin{array}{l}\text { Propylene } \\
\text { glycol }\end{array}$ & $15 \%$ & Nipasol & $0.02 \%$ & Nipasol & $0.02 \%$ & Nipasol & $0.02 \%$ \\
\hline Nipagin & $0.25 \%$ & Nipagin & $0.25 \%$ & Nipagin & $0.15 \%$ & Nipagin & $0.15 \%$ & Nipagin & $0.15 \%$ \\
\hline \multirow[t]{5}{*}{ Aquadest } & $\begin{array}{c}\text { Ad } 10 U \\
\%\end{array}$ & Aquadest & $\begin{array}{c}\text { Ad } 1 U U \\
\%\end{array}$ & $\begin{array}{l}\text { Natrosol } \\
\mathrm{HBr}\end{array}$ & $0,3 \%$ & $\mathrm{KOH} \mathrm{10 \%}$ & q.s. & $\mathrm{KOH} \mathrm{10 \%}$ & q.s. \\
\hline & & & & Glycerine & $1 \%$ & Glycerine & $1 \%$ & Glycerine & $1 \%$ \\
\hline & & & & $\begin{array}{l}\text { Propylene } \\
\text { glycol }\end{array}$ & $5 \%$ & $\begin{array}{l}\text { Propylene } \\
\text { glycol }\end{array}$ & $5 \%$ & $\begin{array}{l}\text { Propylene } \\
\text { glycol }\end{array}$ & $5 \%$ \\
\hline & & & & Aquadest & $\begin{array}{c}\text { Ad } 1 \text { uU } \\
\%\end{array}$ & Aquadest & $\begin{array}{c}\text { Ad } 1 \text { UU } \\
\%\end{array}$ & $\begin{array}{l}\text { Keltrol- } \\
\text { CGSFT }\end{array}$ & $1 \%$ \\
\hline & & & & & & & & Aquadest & $\begin{array}{c}\text { Ad } 100 \\
\%\end{array}$ \\
\hline
\end{tabular}

\subsection{Physical Characterization of Formula \\ 2.3.1. Spreadability Test}

The test was done by placing 0.5 gram cream or gel in the centre of the glass of the spreadability test equipment, then covered it with another glass that has been weighed first. Count the time until one minute and then measure the spread diameter of the cream or gel then make an average diameter from several sides. Add 50gram load on the cover glass then left it for one minute and measure the spread diameter. Continue add loads in multiples of 50 grams and measure every 1 minute to a total of the heaviest load is 250 grams and obtained a sufficient diameter to see the effect of the load on changes in diameter spread of the gel or cream. Spreadability was carried out at room temperature [14,15].

\subsubsection{Stickiness test}

Stickiness test was carried out by using stickiness test equipment. The test was done by placing 0.1 gram gel or cream between two object glass on determined area. Then put one $\mathrm{kg}$ load on the object glass and let it be for 5 minutes. After that, set the object glasses on the test equipment which has been installed with 10 gram load for pulling the object glass. Record the time when the object glasses separating $[14,15]$.

\subsection{3. $\mathrm{pH}$ measurement}

The $\mathrm{pH}$ measurement of microemulsion was performed by using $\mathrm{pH}$-meter. First the electrode was calibrated with standard buffer solution $\mathrm{pH} 4$ and $\mathrm{pH}$ 7. Then, the electrode was immersed into the sample solution (1:9). The $\mathrm{pH}$ values appearing on the screen were recorded [16].

\subsubsection{Viscosity Test}

Viscosity test was carried out using Viscometer Brookfield. Put the gel or cream inside a container which contain 30 grams of it. Put the spindle in the center of gel or cream until it submerged and read the viscosity at speed of $100 \mathrm{rpm}$ on the 10th second. Gel or cream with different consistency might use different spindle number. Spindle; number 5 for Formula 5; spindle number 6 for Formula 1, Formula 3, and Formula 4; and spindle number 7 for Formula 2. This method was carried out in room temperature $[14,15]$. 


\subsubsection{Syneresis Test}

Syneresis test was needed for gel preparations to determine the event of discharge of water from the semisolid preparations such as gel. The result is the gel looked smaller and denser. In this study only Formula 1 and Formula 2 preparations which are gels and the other formulas are cream. Syneresis test was carried out by weighing 10 grams of gel placed on a porcelain dish and covered with plastic wrap. The porcelain dish then being stored at $10^{\circ} \mathrm{C}$ by putting it in the refrigerator and weight its weight continuously at 24,48 , and 72 hours. Before weighing, remove the plastic wrap first and also remove the dew liquid on the cup using tissue. The occurrence of syneresis known from the calculation of the decrease in stock weight during storage phase and compare with its initial weight $[14,15]$.

Weight percentage reduction $=($ Initial weight-after storage weight $) /($ initial weight $) \times 100 \ldots . . .(1)$

\subsubsection{Effect of Centrifugation Test}

Centrifugation test was needed for cream preparations to see the degree of separation by putting cream preparations on short test tubes the centrifuge it at $3750 \mathrm{rpm}$ for 20 minutes using a centrifuge. The result of this test is degree of separation from the phase separation that occurs in the cream $[14,15]$.

\subsubsection{Scavenging activity against DPPH radical Test}

Scavenging activity was conducted using method spectrophotometer $[9,10]$ with modification. Briefly, each gel or cream preparation was weighed 1.5 grams, then dissolved in ethanol p.a. little by little then it is transferred to a $10 \mathrm{~mL}$ measuring flask and ethanol is added to the anchorage. Preparation dispersions in ethanol p.a. then it was certified for 20 minutes to maximize the preparation of the dissolution process. Dispersed preparations were then transferred to a short test tube to be centrifuged in order to cause the dissolved and insoluble parts. The dissolved part is then filtered using ordinary filter paper and the filtering results are filtered back using Whatman filter paper Number 42 . The second filtering result then becomes a stock solution containing $1.5 \mathrm{mg} / \mathrm{mL}$ extract.

From this solution, a series concentration was prepared in the 96-well plate ELISA and added DPPH radical solution of $40 \mu \mathrm{L}$ and ethanol until the amount of solution in the well is $200 \mu \mathrm{L}$. The solution is then left to stand for 30 minutes at room temperature and dark place before reading the absorbance at $517 \mathrm{~nm}$. IC 50 was investigated based on linear regression equation of series sample concentration vs inhibition (\%).

\subsubsection{Determination of anti-elastase activity}

The measurement of anti-elastase activity was carried out based on the product manual method of Drug Discovery Kit (Neutrophil Elastase Colorimetric and MMP-1 Colorimetric Drug Discovery Kit) [17]. A buffer solution containing $10 \mathrm{mM}$ HEPES was prepared, $50 \mathrm{mM} \mathrm{NaCl}$ and $0.05 \%$ Tween 20 in DMSO. Sample solutions were made in series concentrations from $5-1000 \mu \mathrm{g} / \mathrm{ml}$. Piped $20 \mu \mathrm{l}$ of sample solution was put into 96 well plate and added with buffer solution $65 \mu$ l. Elastatinal $(100 \mu \mathrm{M})$ was used as a control inhibitor, $95 \mu \mathrm{l}$ of buffer solution as blank, and $85 \mu \mathrm{l}$ of buffer solution as a negative control. Neutrophil elastase enzyme $(2.2 \mu \mathrm{U} / \mu \mathrm{l})$ was added to 36 in the sample solution, negative control solution and control inhibitor by $10 \mu \mathrm{l}$ (blank not added by enzyme). Incubated for 30 minutes at $3^{7 \circ} \mathrm{C}$ and then added $5 \mu \mathrm{l}$ of the substrate (MeOSuc-Ala-Ala-Pro-Val-pNA, $100 \mu \mathrm{M}$ ) to each well and measured uptake at $405 \mathrm{~nm}$ wavelength using ELISA reader observed at 1minute intervals during 10 minutes. Percentage of enzyme activity obtained from slope (velocity (v) inhibitor (sample) to the control slope with the formula:

$$
\% \text { Remaining of enzyme activity }=(\mathrm{v} \text { inhibitor }) /(\mathrm{v} \text { kontrol }) \times 100 \%
$$

\subsubsection{Determination of anti-collagenase activity}

The measurement of anti-collagenase activity was carried out based on the product manual method of Drug Discovery Kit (Neutrophil Elastase Colorimetric and MMP-1 Colorimetric Drug Discovery Kit). A buffer solution containing $50 \mathrm{mM}$ HEPES was prepared, $10 \mathrm{mM} \mathrm{CaCl2,} \mathrm{0.05 \%} \mathrm{Brij-35}$ 
and $1 \mathrm{mM}$ DTNB in DMSO. A series of sample solution concentrations were made from 5-1000 $\mu \mathrm{g} / \mathrm{ml}$. Piped $20 \mu \mathrm{l}$ of the sample solution and added $50 \mu \mathrm{l}$ of the buffer solution to the 96 well plate. NNGH (N-Isobutyl-N- (4-methoxyphenylsulfonyl) glycylhydroxamic acid; $1.3 \mu \mathrm{M}$ ) was used as a control inhibitor to be used as a comparison. The buffer solution was $90 \mu \mathrm{l}$ as a blank and $70 \mu \mathrm{l}$ buffer solution as a negative control. A total of $20 \mu \mathrm{l}$ of the MMP-1 enzyme (153 mU / $\mu \mathrm{l})$ was added to the well containing the sample, negative control and control inhibitors (no enzyme added blanks). Incubated for 30 minutes at $37^{\circ} \mathrm{C}$, then each well was added with $10 \mu \mathrm{l}$ of the substrate (thiopeptide, Ac-PLG- [2mercapto-4-methyl-pentanoyl]-LG-OC $2 \mathrm{H}_{5} ; 100 \mu \mathrm{M}$ ) and measured absorption at $410 \mathrm{~nm}$ wavelength using ELISA reader. Observations were carried out every 1minute interval for 10 minutes. Percentage of enzyme activity obtained from slope (velocity (v) inhibitor (sample) to the control slope with the formula:

$\%$ Remaining of enzyme activity $=(\mathrm{v}$ inhibitor $) /(\mathrm{v}$ kontrol $) \times 100 \%$

\subsubsection{Determination of anti-tyrosinase activity}

Testing of inhibitory activity against tyrosinase was carried out by using L-Dopa as a substrate and kojic acid as a positive control [18]. Each sample was made a series of concentrations from 100-1000 $\mu \mathrm{g} / \mathrm{mL}$ and $30 \mu \mathrm{L}$ were taken each and $125 \mu \mathrm{L}$ phosphate buffer $(0.1 \mathrm{M}, \mathrm{pH} 6.8)$ was added, $5 \mu \mathrm{L}$ of the tyrosinase enzyme ( 2500 units $/ \mathrm{mL})$, incubated for 30 minutes at $37^{\circ} \mathrm{C}$. Then added $40 \mu \mathrm{L}$ of LDOPA $(2.5 \mathrm{mM})$ and incubated for 30 minutes at room temperature $\left(25^{\circ} \mathrm{C}\right)$, then measured the absorbance at a wavelength of $515 \mathrm{~nm}$. Also carried out measurements of blanks and positive control of kojic acid. Tyrosinase enzyme inhibition activity is expressed as the $\mathrm{IC}_{5} 0$ value. The percentage of inhibition is calculated by the formula:

Percentage of Inhibition $=$ (Negative control absorbance-Sample absorbance $) /($ Negative control absorbance) $\times 100 \%$

\subsubsection{Determination of stability}

Stability test was done using freeze-thaw method for 3 times cycle with the duration 4 hours per cycle. The freeze temperature was $-20^{\circ} \mathrm{C}$, while thawing temperature was $30^{\circ} \mathrm{C}$.

\section{RESULTS AND DISCUSSION}

Previous study reported that the optimum concentration of extract that can be formulated into topical preparation (both for gel and cream) was 1\% contains ethanolic extract of strawberry, pomelo peel skin, and langsat peel in ratio of [11-13]. Using the dose of extract, topical preparation can be accepted by consumer because the appearance and colour of product can be tolerated. Table 2 below shown the physical properties of all formula produced in this research according to the composition as in Table 1. Based on the results of $\mathrm{pH}$ measurement, it was known that all formula was relative acid with $\mathrm{pH}$ around 5 and still in accordance with the rules for topical preparation that does not cause skin irritation. Physical treatment by freezing-thawing didn't influence acidity of formula. Cream produced using Formula 1 has the highest $\mathrm{pH}$ and still acceptable to be applied on the skin.

All formulas have good stability after centrifugation process. There is no differences appearance both of cream and gel after treatment. Syneresis test result shown that all formulas were stable, there is no loss weight after process. Physical parameters of all formulas meet the requirements for a good topical preparation. 
Table 2. Physical parameters of all formulas

\begin{tabular}{|c|c|c|c|c|c|c|}
\hline Parameter & Time & Formula 1 & Formula 2 & Formula 3 & Formula 4 & Formula 5 \\
\hline \multirow{2}{*}{$\begin{array}{l}\text { Spreadability } \\
\left(\mathrm{cm}^{2}\right)\end{array}$} & $\mathrm{H}_{0}$ & $33.25 \pm 0.78$ & $9.00 \pm 0.90$ & $32.89 \pm 2.53$ & $49.69 \pm 2.99$ & $36.17 \pm 2.61$ \\
\hline & $\mathrm{H}_{1}$ & $39.61 \pm 11.28$ & $8.22 \pm 0.42$ & $27.70 \pm 2.95$ & $36.17 \pm 0.45$ & $37.17 \pm 4.41$ \\
\hline \multirow{2}{*}{$\begin{array}{c}\text { Stickiness } \\
\text { (detik) }\end{array}$} & $\mathrm{H}_{0}$ & $3, .3 \pm 0.12$ & $24.73 \pm 0.81$ & $1.57 \pm 0.06$ & $<1$ & $0.74 \pm 0.11$ \\
\hline & $\mathrm{H}_{1}$ & $1.42 \pm 0.07$ & $34.67 \pm 19.42$ & $1.67 \pm 0.12$ & $1.42 \pm 0.12$ & $0.50 \pm 0.09$ \\
\hline \multirow{2}{*}{$\mathrm{pH}$} & $\mathrm{H}_{0}$ & $5.28 \pm 0.02$ & $4.83 \pm 0.07$ & $4.94 \pm 0.02$ & $4.71 \pm 0.01$ & $4.71 \pm 0.20$ \\
\hline & $\mathrm{H}_{1}$ & $5.22 \pm 0.02$ & $4.83 \pm 0.12$ & $4.86 \pm 0.01$ & $4.58 \pm 0.03$ & $4.45 \pm 0.01$ \\
\hline \multirow{2}{*}{$\begin{array}{c}\text { Viscosity } \\
\text { (mPas) }\end{array}$} & $\mathrm{H}_{0}$ & $9.040 \pm 839.68$ & $17,142.5 \pm 909.3$ & $1,580 \pm 14.14$ & $1.340 \pm 14.14$ & $826 \pm 9.52$ \\
\hline & $\mathrm{H}_{1}$ & $2,391 \pm 115.49$ & $23,850 \pm 840.56$ & $2,787.5 \pm 59.09$ & $3,430 \pm 147.20$ & $711 \pm 13.61$ \\
\hline \multirow{2}{*}{$\begin{array}{c}\text { Effect of } \\
\text { centrifugation }\end{array}$} & $\mathrm{H}_{0}$ & stable & stable & stable & stable & stable \\
\hline & $\mathrm{H}_{1}$ & stable & stable & stable & stable & stable \\
\hline Syneresis & & stable & stable & stable & stable & stable \\
\hline
\end{tabular}

Note: Ho is data observed before physical stability test

H1 is data observed after physical stability test

Aging is a natural process that is closely related to degenerative processes. The occurrence of free radicals due to oxidative processes is the basis of the most commonly adopted theory. Antioxidants are one of the efforts that are often carried out to prevent aging. Extrinsic skin aging is dominated by exposure to solar radiation (photo aging) [5]. Free radicals are formed because of oxidative stress, which is a major cause of intrinsic and extrinsic aging. The use of antioxidants is one effort that is often done to prevent aging or at least aging healthily [19]. The result of scavenging activity that also expressed antioxidant capacity can be seen in Table 3. DPPH is usually used as a substrate to evaluate the antioxidant activity of antioxidants (the unpaired electron is delocalized over $\mathrm{N}$ atoms and over $\mathrm{O}$ atoms, respectively) [20]. Based on this result, Formula 5 has the highest antioxidant activity among other Formulas. The Formula 5 also shown good stability, because there are no significant differences in term of antioxidant activity between before and after storage and physical stability test.

Table 3. Scavenging radical DPPH activityof all formulas

\begin{tabular}{lccccccc}
\hline \multirow{2}{*}{ Parameter } & Time & Formula 1 & Formula 2 & Formula 3 & Formula 4 & Formula 5 \\
& & & & & & & \\
& $\begin{array}{c}0,225 \\
\mathrm{mg} / \mathrm{mL}\end{array}$ & $\mathrm{H}_{0}$ & $38.49 \pm 3.66$ & $43.81 \pm 2.54$ & $41.49 \pm 3.35$ & $45.36 \pm 3.24$ & $41.36 \pm 1.85$ \\
\cline { 2 - 8 } & $\mathrm{H}_{1}$ & $44.43 \pm 4.74$ & $43.91 \pm 0.85$ & $38.63 \pm 3.51$ & $45.04 \pm 2.42$ & $37.74 \pm 1.79$ \\
\hline \multirow{2}{*}{$\begin{array}{c}\text { Scavenging } \\
\text { activity }(\%)\end{array}$} & $\begin{array}{c}0,450 \\
\mathrm{mg} / \mathrm{mL}\end{array}$ & $\mathrm{H}_{0}$ & $52.94 \pm 1.16$ & $62.57 \pm 2.12$ & $50.83 \pm 1.82$ & $63.07 \pm 0.79$ & $65.56 \pm 3.02$ \\
\cline { 2 - 8 } & $\begin{array}{c}0,675 \\
\mathrm{mg} / \mathrm{mL}\end{array}$ & $\mathrm{H}_{0}$ & $62.95 \pm 1.56$ & $78.07 \pm 1.35$ & $60.34 \pm 2.17$ & $76.67 \pm 2.30$ & $76.16 \pm 4.63$ \\
\cline { 2 - 8 } & $\mathrm{H}_{1}$ & $68.17 \pm 0.48$ & $77.58 \pm 2.79$ & $69.96 \pm 3.22$ & $77.84 \pm 0.67$ & $73.79 \pm 2.15$ \\
\hline
\end{tabular}

Note: Ho is data observed before physical stability test

$\mathrm{H} 1$ is data observed after physical stability test

Collagen is one of the major components of connective tissue on the skin. Collagen is the most abundant protein in the extracellular matrix (ECM) and is responsible for the elasticity of skin strength and maintains its flexibility [21]. However, collagen is known to be rapidly degraded by collagenase primarily in the presence of reactive oxidative species and smoke habit (Karim). Collagenase enzyme is a metalloproteinase matrix (MMPs) that can decrease molecules such as aggrekan, elastin, fibronectin, gelatin, laminin, and collagen [22]. Under normal conditions, the skin will produce elastase and collagenase enzymes. However, the increase in free radicals in the body will accelerate the production of these enzymes, so that the degradation of collagen which is the extracellular matrix of the dermis will be faster. Based on Fig.1. it can be described that collagenase and elastase inhibition of 
Formula was influenced by freeze-thawing process during stability experiment and also depended on the concentration of Formula used in measurement.

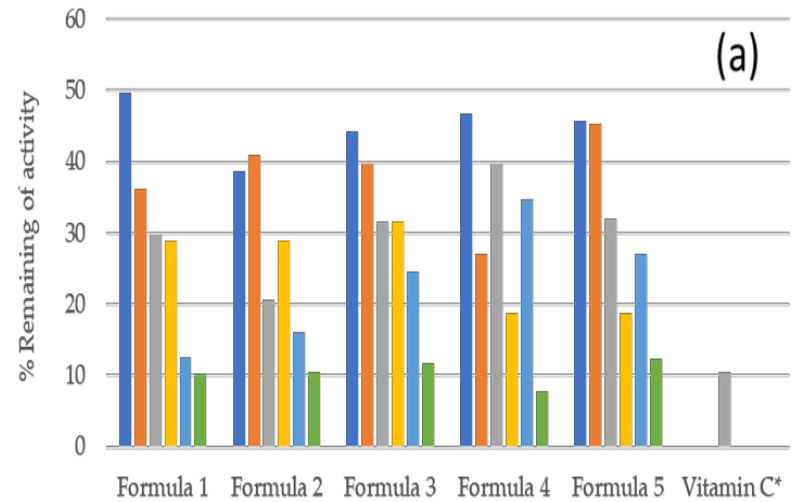

$\llbracket 50 \mathrm{mg} / \mathrm{mL} \mathrm{HO} \square 50 \mathrm{mg} / \mathrm{mLH} 1 \square 100 \mathrm{mg} / \mathrm{mL} \mathrm{H} 0$

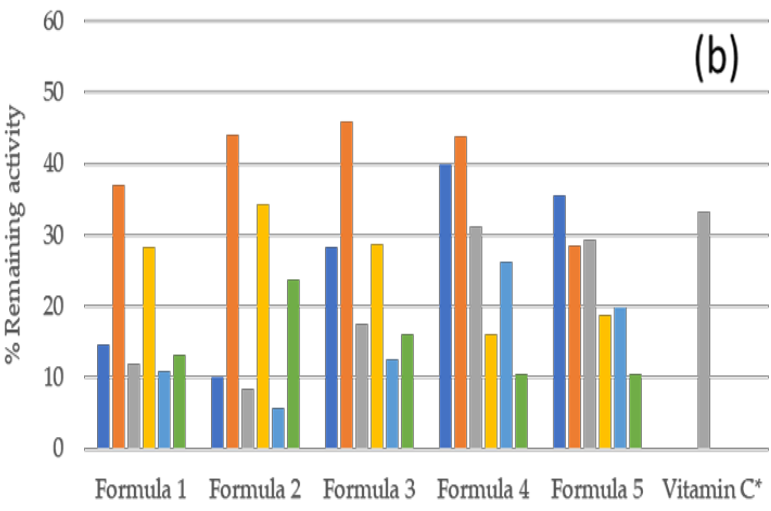

$\square 100 \mathrm{mg} / \mathrm{mL} \mathrm{H} 1 \square 200 \mathrm{mg} / \mathrm{mL} \mathrm{HO} \square 200 \mathrm{mg} / \mathrm{mL} \mathrm{H1}$

Figure 1. Activity of formula in collagenase (a) and elastase (b) inhibition

Exposure to UV light can also as trigger skin pigmentation due to increased production of melanin by the tyrosinase enzyme [23]. Based on the data $\mathrm{IC}_{50}$ of tyrosinase activity in Fig.2., all formulas have anti-tyrosinase activity. However, their activities were lower than kojic acid (IC50 111.04 $\pm 0.15 \mu \mathrm{g} / \mathrm{mL}$ ) or around 4-10 times lower than kojic acid [24]. There are significant differences between before and after freeze-thaw treatment. The inhibition of formula for tyrosinase, elastase and collagenase enzyme can be evaluated in this research. Inhibition activity of formula against collagenase was lower than activity of vitamin $C$ which has \% remaining enzyme activity around 33\% [25]. Profile inhibition of all formula cannot be described clearly. Many factors influenced in this study, such as in preparation step and various condition in determination primarily in handling freeze and thaw treatment. The ability of extracts mixture into microemulsion system to inhibit collagenase activity is decrease after freeze thaw cycle because chemical instability.

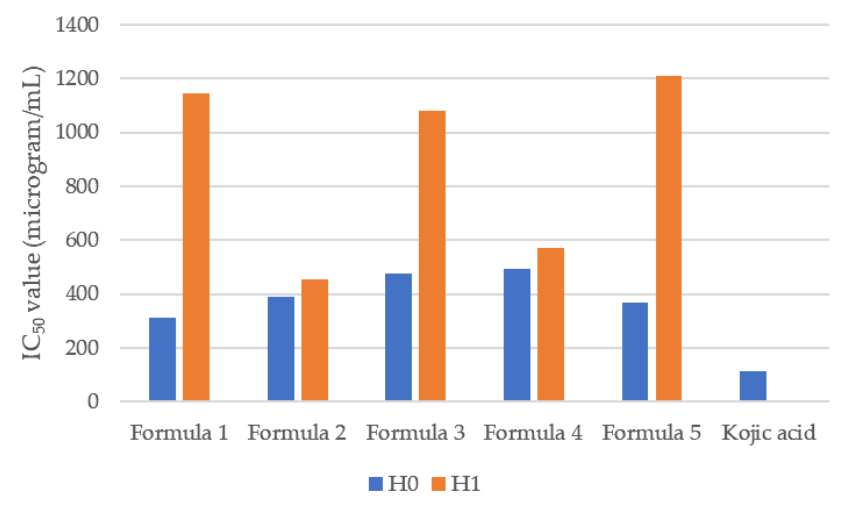

Figure 2. Inhibition activity of Formula against to tyrosinase enzyme

According to Fig. 1 and 2 and, it can be seen that the ability of all formula to inhibit collagenase and elastase enzyme is decrease after freeze thaw cycle. It might be caused by chemical instability. Flavonoid as one of active compounds in extract could be form a chalcone which further degraded to brown product that has a low inhibition activity [26]. Nevertheless, these formulas still have opportunity to develop as topical preparation including cosmetics for anti-aging activity. 


\section{CONCLUSION}

It can be concluded that topical preparations with active substances a mixture of ethanolic extract of strawberry fruit, pamelo peel, and langsat fruit can be develop as antiaging product. All formulas have good stability and activity in radical DPPH scavenging, anti-elastase, anti-collagenase, and antityrosinase activity.

\section{ACKNOWLEDGMENTS}

Many thanks to Directorate of Research of Gadjah Mada University and Team in Advance Pharmaceutical Sciences Laboratory for nice collaboration. This research was funded by Ministry of Research, Technology and Higher Education-Indonesia with grant number 1959/UN1/DITLIT/DITLIT/LT/2018.

\section{CONFLICTS OF INTEREST}

The authors declare no conflict of interest.

\section{REFERENCES}

1. Sparavigna A, Tateo A, Inselvini E, Tocchio M, Orlandini MC, Botali G. Anti-Age Activity and Tolerance Evaluation of Collagen Micro-Injection Treatment Associated to Topical Application of a Cosmetic Formulation (Investigator-Initiated Multicentre Trial). J Clin Exp Dermatol Res. 2017;08(03).

2. Farage MA, Miller KW, Elsner P, Maibach HI. Structural characteristics of the aging skin: A review. Cutan Ocul Toxicol. 2007;26(4):343-57.

3. Landau M. Exogenous factors in skin aging. Curr Probl Dermatol. 2007;35:1-13.

4. Tobin DJ. Introduction to skin aging. J Tissue Viability [Internet]. 2017;26(1):37-46. Available from: http://dx.doi.org/10.1016/j.jtv.2016.03.002

5. Lephart ED. Equol's anti-aging effects protect against environmental assaults by increasing skin antioxidant defense and ECM proteins while decreasing oxidative stress and inflammation. Cosmetics. 2018;5(1):1-17.

6. Giampieri F, Alvarez-Suarez JM, Mazzoni L, Forbes-Hernandez TY, Gasparrini M, GonzàlezParamàs AM, et al. Polyphenol-rich strawberry extract protects human dermal fibroblasts against hydrogen peroxide oxidative damage and improves mitochondrial functionality. Molecules. 2014;19(6):7798-816.

7. Giampieri F, Alvarez-Suarez JM, Tulipani S, Gonzàles-Paramàs AM, Santos-Buelga C, Bompadre $\mathrm{S}$, et al. Photoprotective potential of strawberry (Fragaria $\times$ ananassa) extract against UV-A irradiation damage on human fibroblasts. J Agric Food Chem. 2012;60(9):2322-7.

8. Zhou Y, Dong Y, Xu Q, He Y, Tian S, Zhu S, et al. Mussel oligopeptides ameliorate cognition deficit and attenuate brain senescence in d-galactose-induced aging mice. Food Chem Toxicol [Internet]. 2013;59:412-20. Available from: http://dx.doi.org/10.1016/j.fct.2013.06.009

9. Kim JH, Byun JC, Bandi AKR, Hyun CG, Lee NH. Compounds with elastase inhibition and free radical scavenging activities from Callistemon lanceolatus. J Med Plants Res. 2009;3(11):914-20.

10. Karim AA, Azlan A, Ismail A, Hashim P, Abd Gani SS, Zainudin BH, et al. and Tyrosinase Inhibitory Activities of Cocoa Pod Extract. BMC Complement Altern Med. 2014;14(381):1-13.

11. Qonita F. Pemanfaatan Ekstrak Buah Strawberry (Fragaria X Ananassa (Duchesne Ex Weston)) Sebagai Bahan Kosmetik: Uji Aktivitas Antiaging dan Antibakteri Secara In Vitro. Yogyakarta: Faculty of Pharmacy, Gadjah Mada University; 2017.

12. Syamsu N. Pemanfaatan Ekstrak Etanolik dan Etil Asetat Daging Buah dan Kulit Buah Langsat (Lansium Domesticum (Corr)) Sebagai Bahan Aktif Kosmetik: Uji Aktivitas Antiaging dan Anti Jerawat Secara In Vitro. Yogyakarta: Faculty of Pharmacy, Gadjah Mada University; 2017.

13. Zulbayu L ode. Uji Aktivitas Antiaging dan Antibakteri Ekstrak Etanol dan Etil Asetat Kulit Buah Jeruk Bali (Citrus maxima L.) secara In Vitro. Yogyakarta: Faculty of Pharmacy, Gadjah Mada University; 2018.

14. Khairunnisa N. Formulasi Gel dan Krim Penangkap Radikal 2,2-Difenil-1-Pikrilhidrazil dari 
Kombinasi Ekstrak Buah Strawberry, Ekstrak Kulit Buah Jeruk Bali dan Ekstrak Buah Langsat serta Uji Stabilitasnya. Yogyakarta: Faculty of Pharmacy, Gadjah Mada University; 2018.

15. Prabaswari N. Formulasi serta Uji Stabilitas Kombinasi Ekstrak Buah Strawberry, Buah Langsat, dan Kulit Buah Jeruk Bali dalam Krim-Penangkap Radikal DPPH (2,2, Difenil-1-Pikrilhidrazin),. Yogyakarta: Faculty of Pharmacy, Gadjah Mada University; 2018.

16. Talegaonkar S, Tariq M, Alabood RM. An Official Publication of Association of Pharmacy Professionals D Esign and Development of O/W nanoemulsion. Bull Pharm Res. 2011;1(3):18-30.

17. Ya Luo, Hao-ru Tang *, Xiao-rong Wang, Yong Zhang ZL. Antioxidant properties and involved antioxidant compounds of strawberry fruit at different maturity stages. J Food, Agric Environ. 2011;9(1):166-70.

18. Lukitaningsih E. and Holzgrabe U., Bioactive Compounds in Bengkoang (Pachyrhizus erosus) AS Antioxidant and Tyrosinase Inhibiting Agents. Indones J Pharm. 2014;25(2):68.

19. Wong SK, Lim YY, Chan EWC. Evaluation of antioxidant, anti-tyrosinase and antibacterrial activities of selected Hibiscus species. Ethobotanical Leafl. 2010;14(June):781-96.

20. Biswas M, Haldar PK, Ghosh AK. Antioxidant and free-radical-scavenging effects of fruits of Dregea volubilis. J Nat Sci Biol Med. 2010;1(1):29-34.

21. Ndlovu G, Fouche G, Tselanyane M, Cordier W, Steenkamp V. In vitro determination of the antiaging potential of four southern African medicinal plants. BMC Complement Altern Med. 2013;13.

22. Klein T, Bischoff R. Physiology and pathophysiology of matrix metalloproteases. Amino Acids. 2011;41(2):271-90.

23. Lukitaningsih E, Holzgrabe U. A New Compound $(8,9)$-Furanyl-Pterocarpan-3-Ol Used for Standardization of Bengkuang (Pachyrhizus erosus) Extract as Sunscreen and Skin Whitening Agent. Indones J Cancer Chemoprevention. 2019;10(2):60.

24. Widasri M. Topical Microemulsion Antiaging Formulation of Strawberry Fruit (Fragaria $\mathrm{x}$ ananassa Duchesne), Langsat Fruit (Lansium domesticum Correa.), Pomelo Peel (Citrus maxima (Burm.) Merr.) Extracts Mixture. Yogyakarta: Faculty of Pharmacy, Gadjah Mada University; 2018.

25. Hermadi Saputro A. Topical Microemulgel Antiaging Formulation of Strawberry Fruit (Fragaria $x$ ananassa Duchesne), Langsat Fruit (Lansium domesticum Correa.), Pomelo Peel (Citrus maxima (Burm.) Merr.) Extracts Mixture. Yogyakarta: Faculty of Pharmacy, Gadjah Mada University; 2018.

26. Sipahli S, Mohanlall V, Mellem JJ. Stability and degradation kinetics of crude anthocyanin extracts from H. sabdariffa. Food Sci Technol. 2017;37(2):209-15.

(C) 2021 by the authors. Submitted for possible open access publication under the terms and conditions of the Creative Commons Attribution (CC BY) license (http://creativecommons.org/licenses/by/4.0/). 